\title{
Transition temperature range of thermally activated nickel-titanium archwires
}

Tatiana Sobottka SPINI ${ }^{1}$, Fabrício Pinelli VALARELLI ${ }^{1}$, Rodrigo Hermont CANÇADO'1, Karina Maria Salvatore de FREITAS ${ }^{1}$, Denis Jardim VILLARINHO²

1- Department of Orthodontics. Ingá Faculty, Maringá, PR, Brazil.

2- Department of Biomedical Materials, Feevale University, Novo Hamburgo, RS, Brazil.

Corresponding address: Rodrigo Hermont Cançado - Departmento de Ortodontia - Faculdade Ingá - Rodovia PR 317, n 6114 - Maringá - PR - Saída para Astorga - 87035-510 - Brasil - Phone/Fax: 554430335009 - e-mail: rohercan@uol.com.br

Submitted: January 29, 2013 - Modification: May 19, 2013 - Accepted: September 11, 2013

\section{ABSTRACT}

\begin{abstract}
bjectives: The shape memory resulting from the superelasticity and thermoelastic effect is the main characteristic of thermally activated NiTi archwires and is closely related to the transition temperature range (TTR). The aim of this study was to evaluate the TTR of thermally activated NiTi archwires commercially available. Material and Methods: Seven different brands of $0.019 " x 0.025^{\prime \prime}$ thermally activated nickel-titanium archwires were tested as received by differential scanning calorimetry (DSC) over the temperature range from $-100^{\circ} \mathrm{C}$ to $150^{\circ} \mathrm{C}$ at $10^{\circ} \mathrm{C} / \mathrm{min}$. Results: All thermally activated NiTi archwires analyzed presented stage transformation during thermal scanning with final austenitic temperature (Af) ranging from $20.39^{\circ} \mathrm{C}$ to $45.42^{\circ} \mathrm{C}$. Three brands of NiTi archwires presented Af close to the room temperature and, this way, do not present properties of shape memory and pseudoelasticity that are desirable in clinical applications. Conclusions: The thermally activated $\mathrm{NiTi}$ archwires present great variability in the TTR and the elastic parameters of each $\mathrm{NiTi}$ archwire should be provided by the manufacturers, to allow achievement of the best clinical performance possible.
\end{abstract}

Keywords: Differential thermal analysis. Orthodontic wires. Materials testing. Nickel. Titanium.

\section{INTRODUCTION}

The NiTi archwires are widely employed in orthodontics because they present shape memory effect and superelasticity combined to good mechanical properties ${ }^{18,19}$.

The shape memory resulting from the pseudoelastic effect (superelasticity) and thermoelastic effect is the main characteristic of these archwires and is closely related to the TTR of each alloy ${ }^{4-7,22}$. The noticeable characteristics of thermally activated nickel-titanium orthodontic archwires are caused by a transformation in the crystalline structure of the alloy, called martensitic transition 5,19,22.

The martensitic transition is initiated when the alloy passes through a critical temperature during cooling called Ms (Martensite start) and is completed at Mf (Martensite finish), when the material is totally martensitic, loses its structure and shape and acquires maximum flexibility. With the increase in temperature, the martensitic transition in austenite is initiated at temperature As (Austenite start) and finalized at Af (Austenite finish), when the $\mathrm{NiTi}$ alloy is totally austenitic, recovering its shape and acquiring maximum rigidity ${ }^{6,14,22}$. As a response to the temperature variation, the crystalline structure presents deformations in the molecular arrangement, without changes in the atomic composition ${ }^{3}$.

Each $\mathrm{Ni}-\mathrm{Ti}$ alloy has a temperature range, in which this phase transition occurs, called transition temperature range (TTR), which should correspond to the temperature variations in the oral environment to be beneficial for the orthodontic treatment ${ }^{5,6,22}$. This information is particularly important in orthodontics, because it determines the mechanical performance of the $\mathrm{NiTi}$ archwire during treatment 5,19,22. However, not all manufacturers provide this information and, 
when they do, it is not always based on reliable information on the TTR of archwires and their clinical performance ${ }^{22}$. Even though some studies have been conducted to evaluate the TTR of thermally activated NiTi archwires, most studies have been performed on smaller round and/or rectangular archwires $4,6,7,20,21$. Information on the TTR of larger rectangular archwires, such as $0.019 " \times 0.025^{\prime \prime}$, is still scarce in the literature.

Therefore, the aims of this study were to evaluate the TTR of thermally activated $\mathrm{NiTi}$ archwires commercially available and mainly to investigate if the Af of these archwires agrees with that provided by the manufacturer. When it is not provided, to determine it and aid the orthodontist in selecting the thermally activated archwires with the greatest benefits for each stage of orthodontic treatment.

\section{MATERIAL AND METHODS}

The study was conducted on seven different brands of 0.019 "x $0.025^{\prime \prime}$ thermally activated nickeltitanium archwires: Nitinol Termoativado (Aditek, Cravinhos, SP, Brazil); NeoSentalloy F200 (GAC, Bohemia, NY, USA); Thermo Plus (Morelli, Sorocaba, $\mathrm{SP}$, Brazil); Copper Ni-Ti $35^{\circ} \mathrm{C}$ (Ormco, Glendora, CA, USA); Flexy Thermal $35^{\circ} \mathrm{C}$ (Orthometric, Marília, SP, Brazil); Superthermal Nickel Titanium Arches (Orthosource, Matão, SP, Brazil) and Heat Activated NiTi (Highland Metals, San Jose, CA, USA) (Figure 1). The wires mentioned above were randomly acquired in the dental market.

One specimen was obtained from the straightest portion of each brand (archwire) carefully trimmed with separating discs under cooling at low speed, connected to a pneumatic sectioning machine, in size of $5 \mathrm{~mm}$ or approximately $5 \pm 0.5 \mathrm{mg}$, weighed in a precision electronic scale with $10 \mu \mathrm{g}$ accuracy.

\begin{tabular}{|c|c|c|c|}
\hline Brand & Manufacturer & Type & Batch \\
\hline Nitinol Termoativado & Aditek & Thermally activated & 51.10 .295091013 \\
\hline NeoSentalloy F200 & GAC & Thermally activated & H580 \\
\hline Thermo Plus & Morelli & Thermally activated & 1590627 \\
\hline Copper Ni-Ti 35 ${ }^{\circ} \mathrm{C}$ & Ormco & Thermally activated & $08 \mathrm{M} 465 \mathrm{M}$ \\
\hline Flexy Thermal 35 $\mathrm{C}$ & Orthometric & Thermally activated & 2041108252 \\
\hline $\begin{array}{c}\text { Superthermal Nickel } \\
\text { Titanium Arches }\end{array}$ & Orthosource & Thermally activated & 9004 \\
\hline Heat Activated NiTi & Highland Metals & Thermally activated & 29350 \\
\hline
\end{tabular}

Figure 1- Thermally activated NiTi archwires analyzed

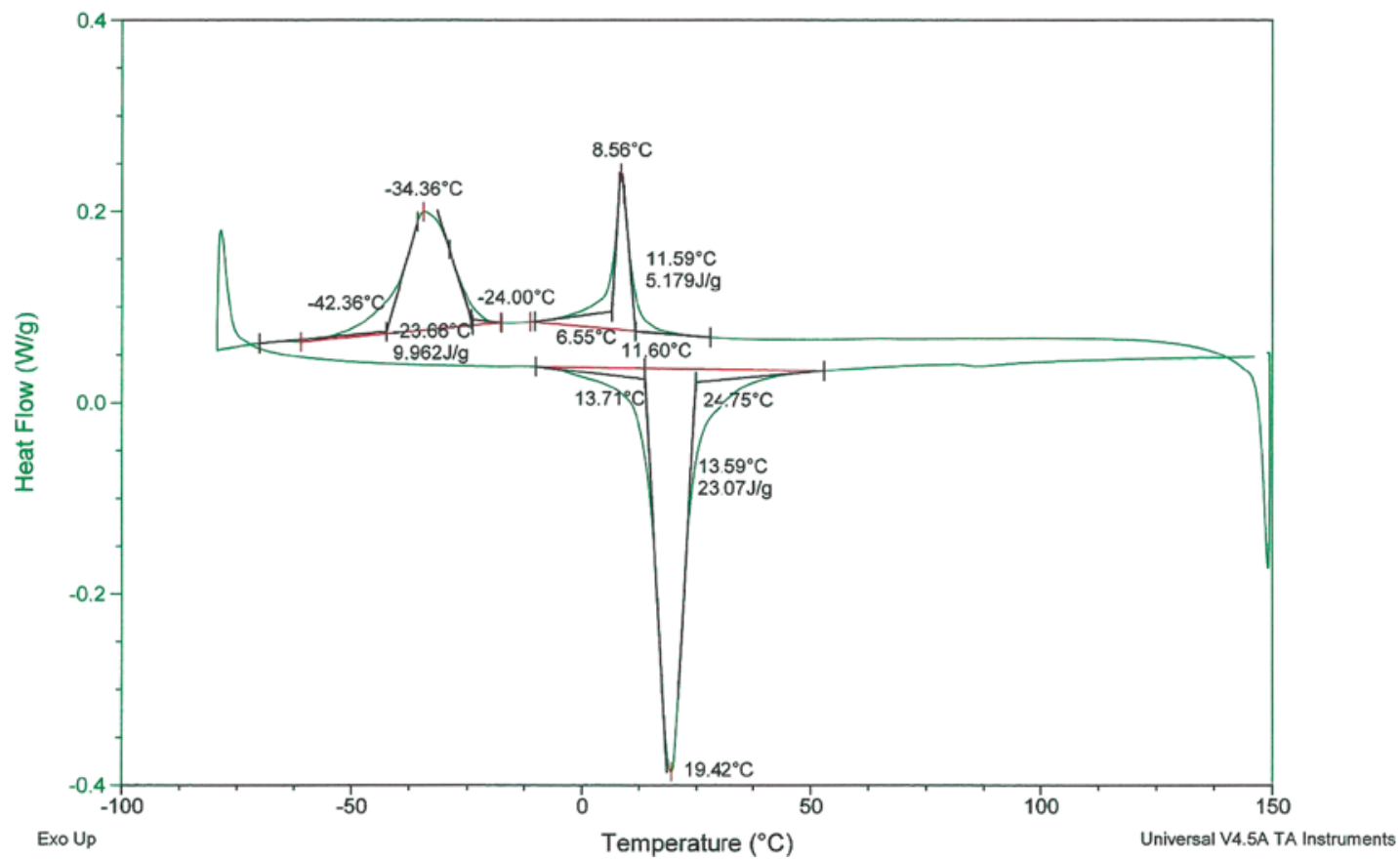

Figure 2- Differential scanning calorimetry (DSC) heating and cooling curves for as-received Nitinol Termoativado 
The care during sectioning of $\mathrm{NiTi}$ archwires was extremely important in the study, to avoid changes in the proportion of austenite and martensite in the NiTi alloy due to mechanical stress. After trimming and weighing, each specimen was cleaned with alcohol, dried and placed in a pan. This pan was covered and sealed and then placed in a DSC (Differential Scanning Calorimetry) machine for thermal analysis of thermally activated NiTi archwires.

The tests were performed following the guidelines of the International Organization for Standardization (ISO), ISO 15841 (ISO, 2006), and American Society for Testing and Materials (ASTM), ASTM D3418-08 (ASTM, 2008)2,15. A DSC machine (model Q20; TA Instruments, New Castle, DE, USA) was used for thermal scanning of thermally activated archwires.

The heating chamber was filled with one nitrogen atmosphere at $50 \mathrm{ml} / \mathrm{min}$, to avoid water condensation and oxidation of the material, and another empty aluminum melting pot was used as

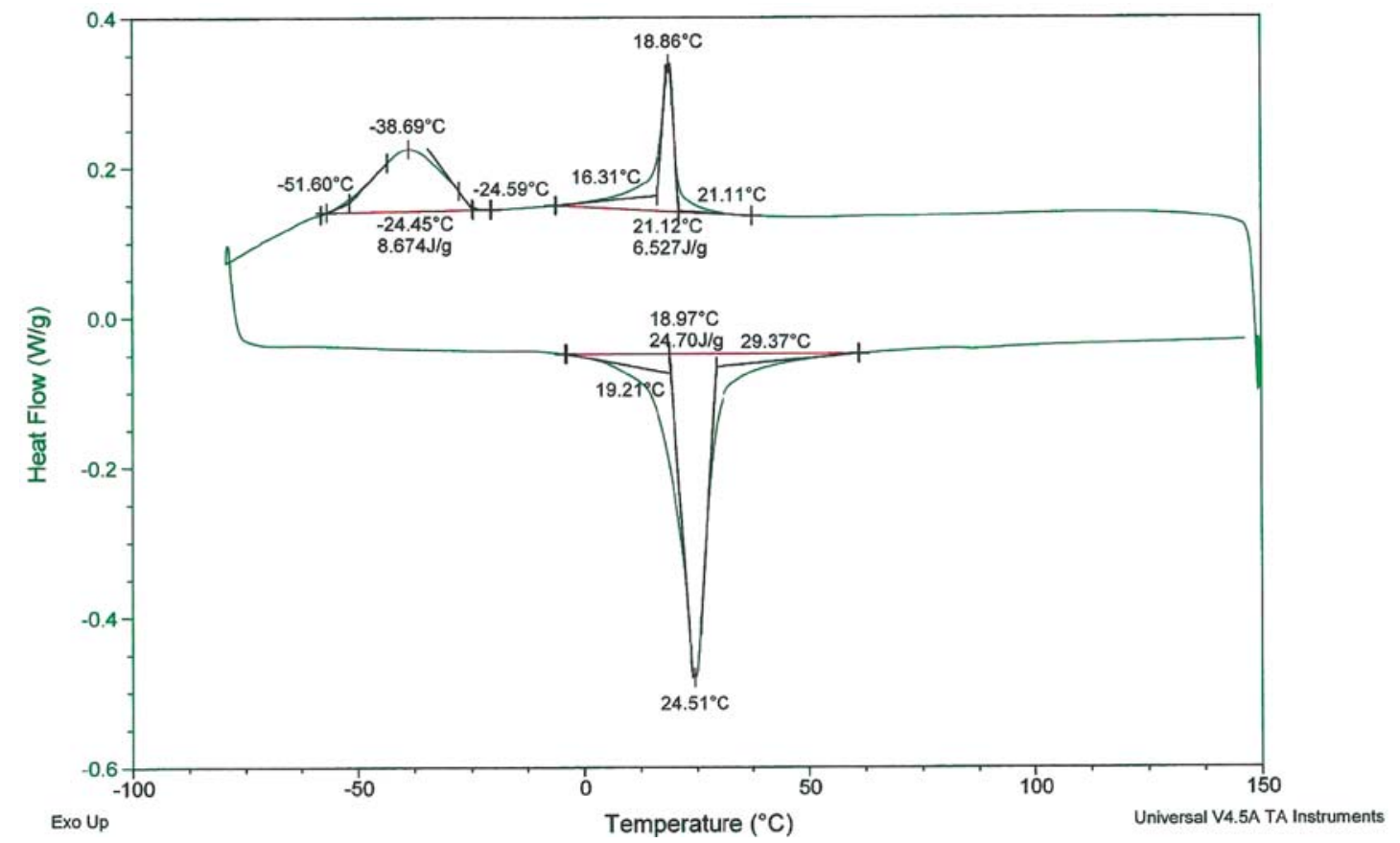

Figure 3- Differential scanning calorimetry (DSC) heating and cooling curves for as-received NeoSentalloy F200

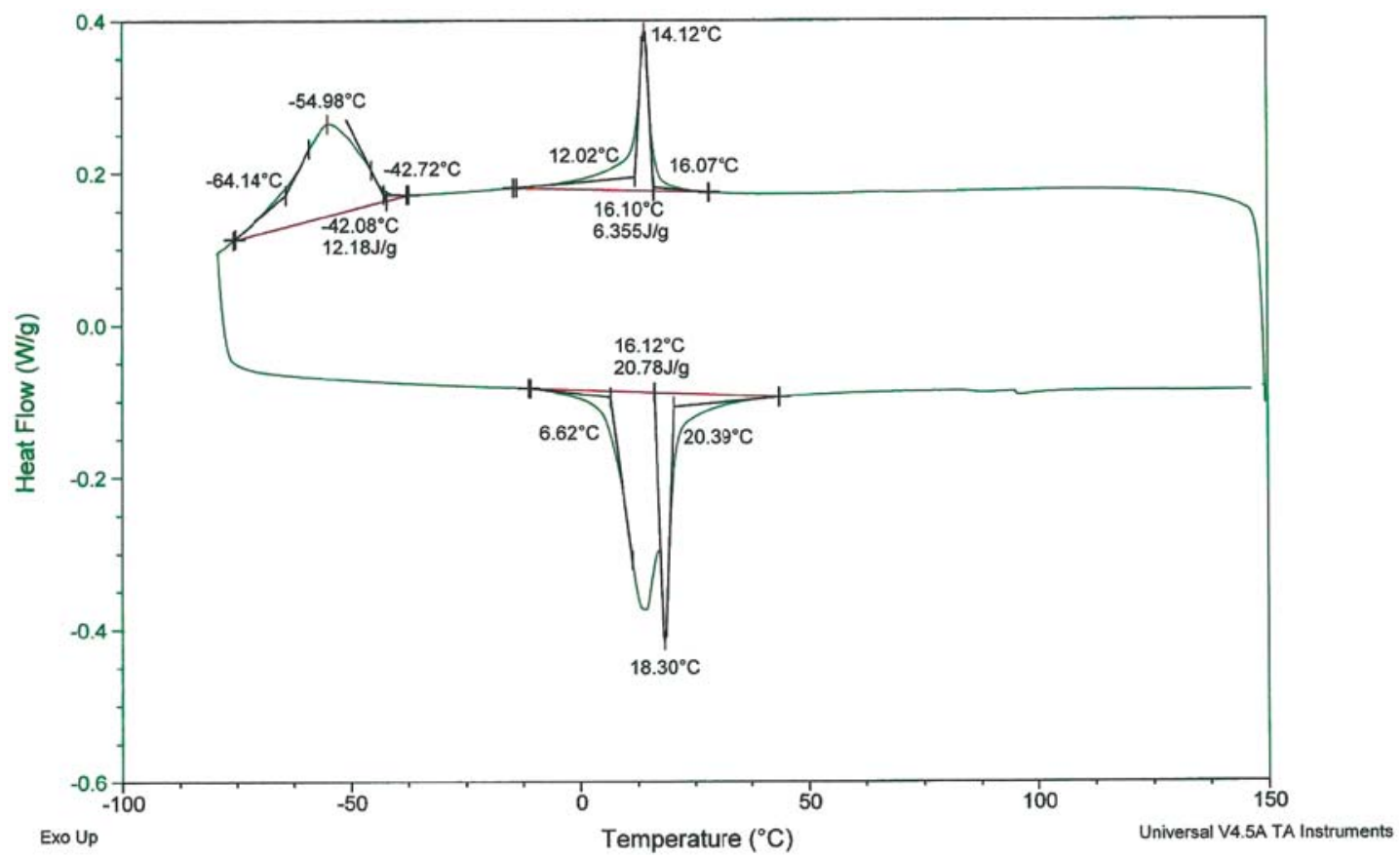

Figure 4- Differential scanning calorimetry (DSC) heating and cooling curves for as-received Thermo Plus 
inert reference. The machine was calibrated right before testing, using mercury/indium as standard. The warming and cooling rates were set at $10^{\circ} \mathrm{C} /$ min, in a temperature range between $-100^{\circ} \mathrm{C}$ and $150^{\circ} \mathrm{C}$. The DSC machine was directly connected to a computer and the software Platinum (TA Instruments, New Castle, DE, USA) exhibited graphs of curves of the exothermic reaction in cooling and endothermic reaction in warming (Figures 2 to 8 ). These graphs (DSC thermograms) provided the enthalpy values and initial and final temperatures of each reaction (endothermic and exothermic) (Figures 2 to 8 ).

The amount of heat released or absorbed during phase transition was recorded according to the temperature (Figures 2 to 8 ). Simultaneously, the transition temperatures [initial austenitic $(\mathrm{Ai})$, final austenitic (Af), initial martensitic (Mi), final martensitic (Mf), initial rhombohedral (Ri) and final rhombohedral (Rf)] were determined by the Platinum Software ${ }^{\circledR}$. The initial and final temperatures of each phase transition were

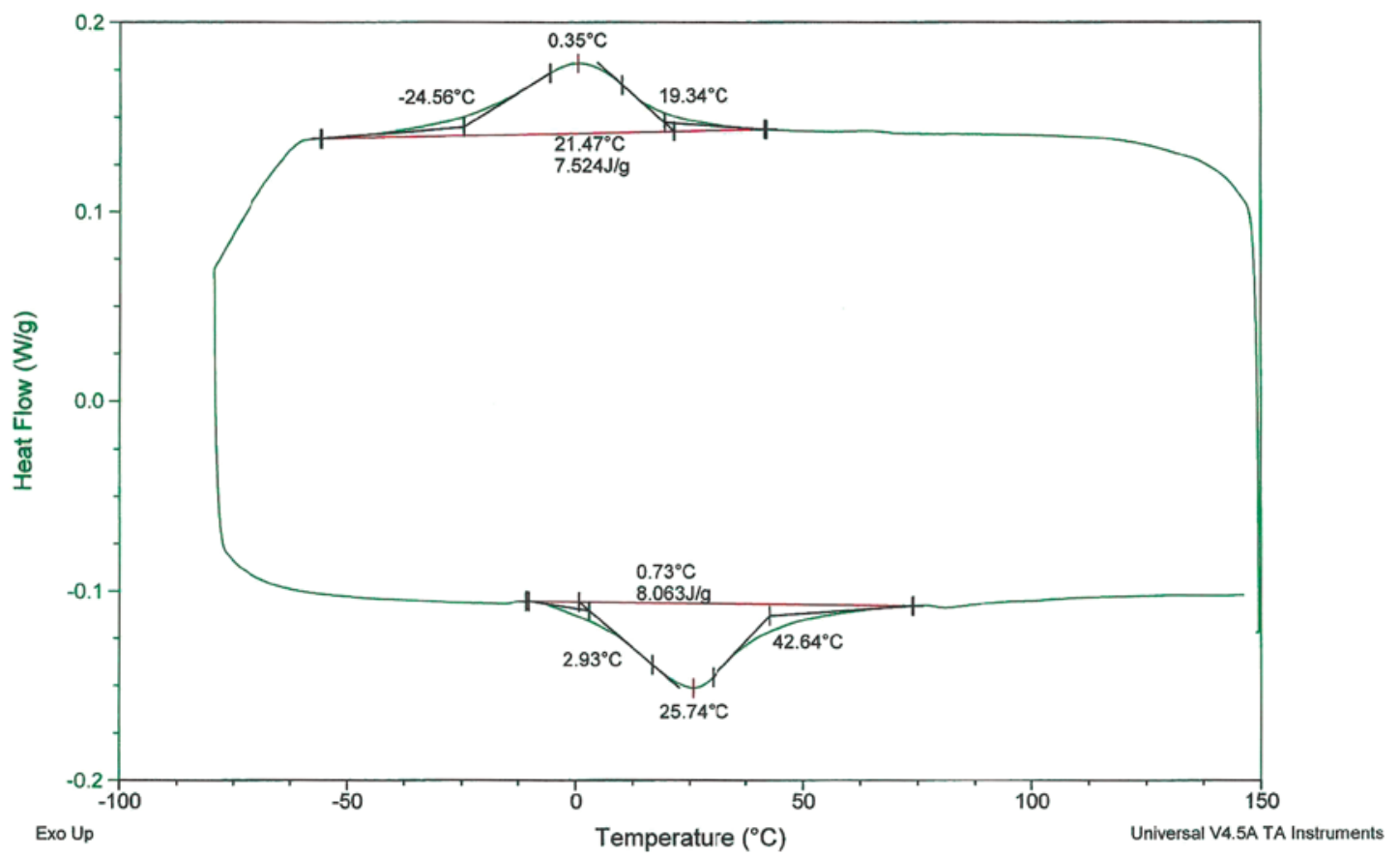

Figure 5- Differential scanning calorimetry (DSC) heating and cooling curves for as-received Copper $\mathrm{Ni}-\mathrm{Ti} 35^{\circ} \mathrm{C}$

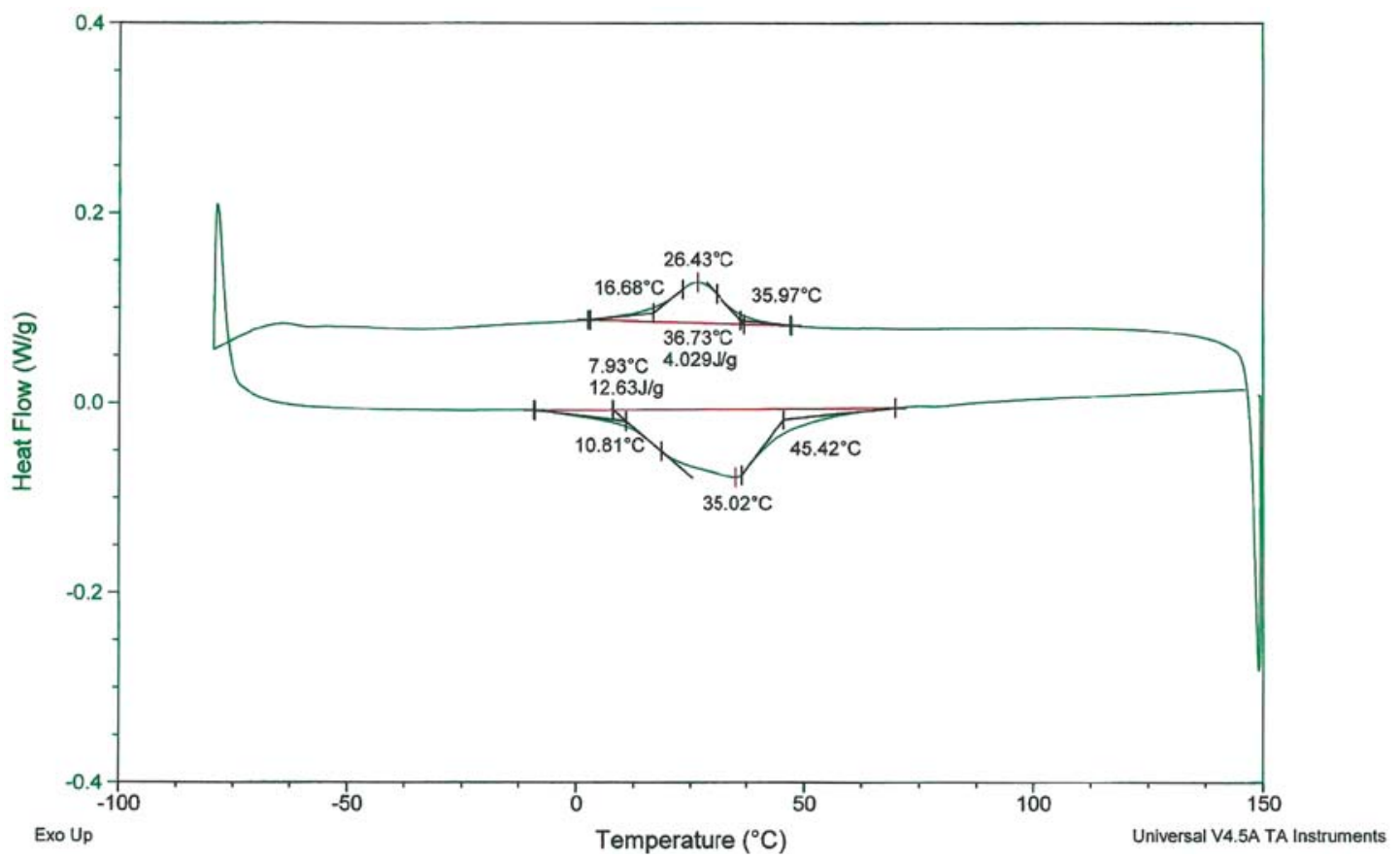

Figure 6- Differential scanning calorimetry (DSC) heating and cooling curves for as-received Flexy Thermal $35^{\circ} \mathrm{C}$ 
determined from lines tangent to the DSC curve, in which there is deviation of adjacent base lines. The rhombohedral phase $(R)$ indicates that the NiTi alloy presents shape memory effect in the two directions.

\section{RESULTS}

All thermally activated $\mathrm{NiTi}$ archwires analyzed presented stage transformation during thermal scanning in the range between $-100^{\circ} \mathrm{C}$ and $150^{\circ} \mathrm{C}$
(Figures 2 to 8 ).

For the thermally activated NiTi archwires Nitinol Termoativado, NeoSentalloy F200, Thermo Plus, Superthermal Nickel Titanium Arches and Heat Activated $\mathrm{NiTi}$ there was presence of rhombohedral phase (R) during cooling. Conversely, none of the archwires presented rhombohedral phase ( $R$ ) during warming (Table 1 ).

The transition temperatures of archwires analyzed are described in Table 1.

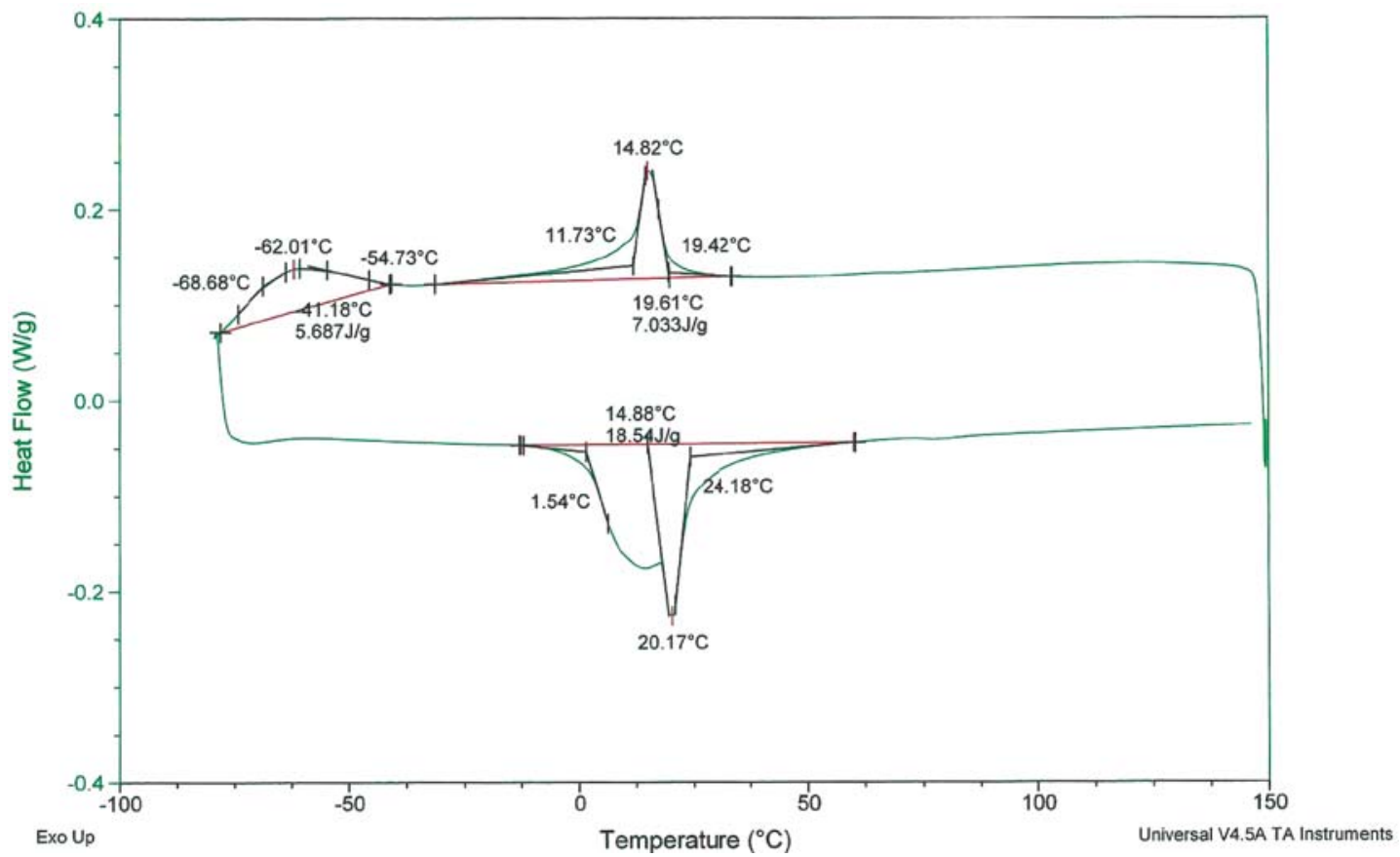

Figure 7- Differential scanning calorimetry (DSC) heating and cooling curves for as-received Superthermal Nickel Titanium Arches

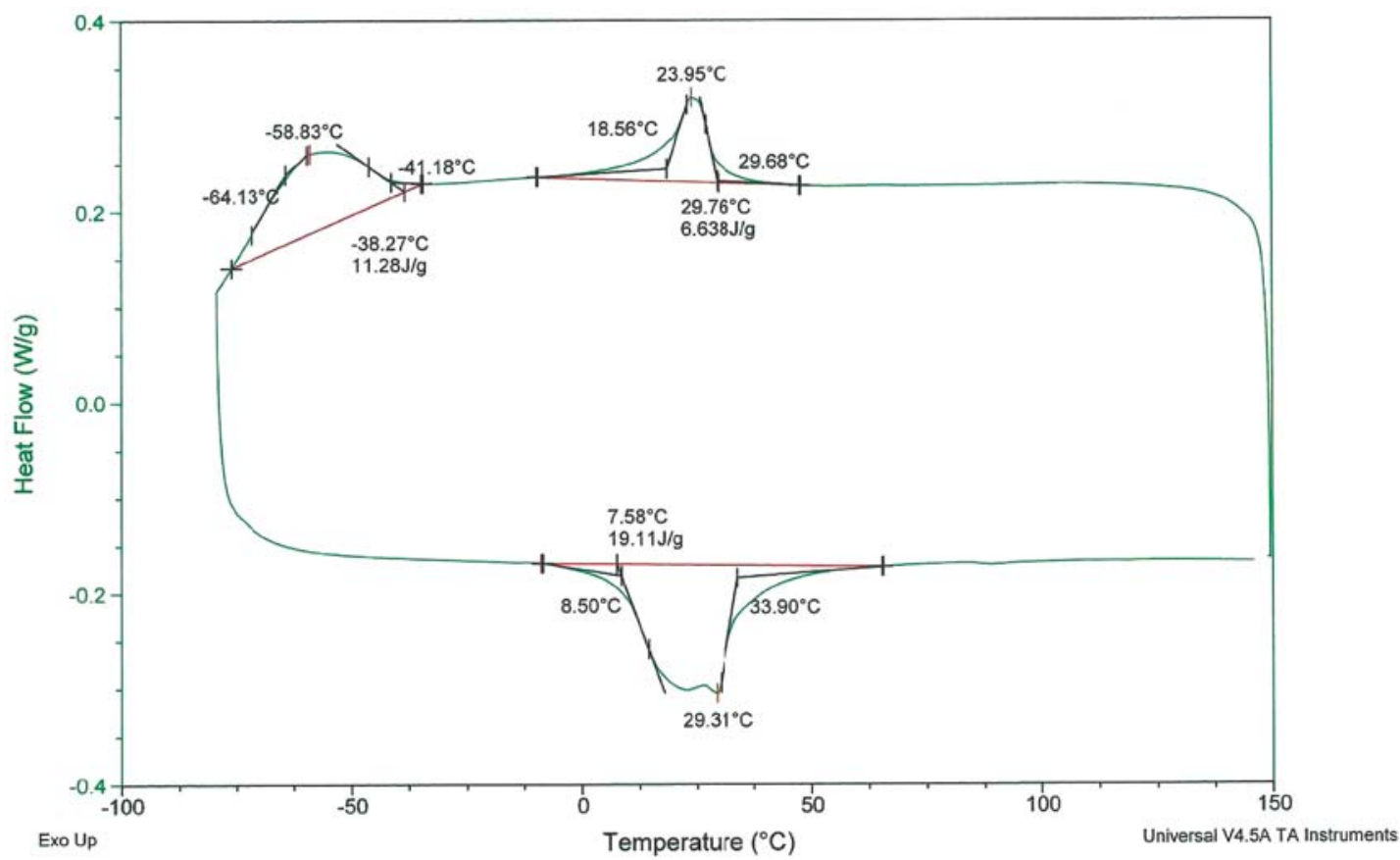

Figure 8- Differential scanning calorimetry (DSC) heating and cooling curves for as-received Heat Activated NiTi 
Table 1- Transition temperatures $\left({ }^{\circ} \mathrm{C}\right)$ of thermally activated $\mathrm{NiTi}$ archwires analyzed

\begin{tabular}{ccccccccc}
\hline Archwires analyzed & \multicolumn{4}{c}{ Cooling } & \multicolumn{3}{c}{ Warming } \\
& $\mathbf{R i}$ & $\mathbf{R f}$ & $\mathbf{M i}$ & $\mathbf{M f}$ & $\mathbf{R i}$ & $\mathbf{R f}$ & $\mathbf{A i}$ & $\mathbf{A f}$ \\
\hline Nitinol Termoativado & 11.60 & 6.55 & -24.00 & -42.36 & --- & --- & 13.71 & 24.75 \\
NeoSentalloy F200 & 21.11 & 16.31 & -24.59 & -51.60 & --- & --- & 19.21 & 29.37 \\
Thermo Plus & 16.07 & 12.02 & -42.72 & -64.14 & --- & --- & 6.62 & 20.39 \\
\hline Copper Ni-Ti 35 ${ }^{\circ} \mathrm{C}$ & --- & --- & 19.34 & -24.56 & --- & --- & 2.93 & 42.64 \\
Flexy Thermal 35 ${ }^{\circ} \mathrm{C}$ & --- & --- & 35.97 & 16.68 & --- & --- & 10.81 & 45.42 \\
\hline $\begin{array}{c}\text { Superthermal Nickel } \\
\text { Titanium Arches }\end{array}$ & 19.42 & 11.73 & -54.73 & -68.68 & --- & --- & 1.54 & 24.18 \\
Heat Activated NiTi & 29.68 & 18.56 & -41.18 & -64.13 & --- & --- & 8.50 & 33.90 \\
\hline
\end{tabular}

The Af of archwires Nitinol Termoativado, Thermo Plus and Superthermal Nickel Titanium Arches was lower or close to the room temperature, and thus there was no phase transition at body temperature (Table 1 ).

The Af of archwires NeoSentalloy F200 and Heat Activated NiTi was close to the body temperature and thus, at room temperature, there is a combination of austenite and martensite in the NiTi alloy, which presents full transition to austenite at the oral temperature (Table 1 ).

The Af of archwires Copper $\mathrm{Ni}-\mathrm{Ti} 35^{\circ} \mathrm{C}$ and Flexy Thermal $35^{\circ} \mathrm{C}$ was higher than the body temperature; thus, at the oral temperature, there is a combination of austenite and martensite in the NiTi alloy (Table 1).

\section{DISCUSSION}

Analysis of the TTR of thermally activated $\mathrm{NiTi}$ archwires is relevant in orthodontics to allow identification of archwires with the best clinical performance. The Af is particularly important, since it indicates the temperature in which the material will entirely return to the original shape and consequently acquire greater rigidity.

The oral temperature presents wide variation during the day because of ingestion of hot and cold foods and drinks, and different areas in the oral cavity present different temperatures. However, experimental studies adopt temperatures between $35^{\circ} \mathrm{C}$ to $37^{\circ} \mathrm{C}$ to reproduce the oral environment ${ }^{1,17,25}$, considering a room temperature around $25^{\circ} \mathrm{C}^{1}$.

The shape memory property of $\mathrm{NiTi}$ alloys does not necessarily imply the application of light and continuous forces in orthodontics ${ }^{22}$. In fact, this property may only be clinically beneficial in orthodontic practice if the Af of NiTi is slightly below the oral temperature, so as the archwire will be mainly in austenitic phase (more rigid) in the oral cavity and almost completely in martensitic phase (more flexible) at room temperature ${ }^{20-22}$. When the alloy is completely transformed into austenite (temperature higher than Af), the load/deflection curve follows the typical performance of other metallic alloys, such as stainless steel, as a direct proportion between force and deformation, without the typical superelastic plateau ${ }^{22}$. That is to say, the $\mathrm{NiTi}$ alloy completely transformed into austenite is definitely more elastic compared to other metallic alloys, yet it does not present superelasticity in the absence of tension ${ }^{22}$.

The DSC method is often employed to evaluate the TTR of thermally activated NiTi archwires, because it allows identification of phase transition temperatures and the quantity of energy released or absorbed during cooling and/or warming. This method, adopted in this study, allows comparison with results of other studies with similar methodology $3,4,6,7,13,14,16,20$.

The present results demonstrate that not all $\mathrm{NiTi}$ archwires present thermal performance that may provide clinical benefits (Table 1) (Figures 2 to 8). Yoneyama, et al. ${ }^{26}$ (1993) employed the DSC method and demonstrated that most orthodontic archwires present TTR between $17^{\circ} \mathrm{C}$ and $32^{\circ} \mathrm{C}$. From a clinical standpoint, archwires with lower Af do not present pseudoelastic behavior in clinical applications. Santoro, Nicolay and Cangialosi ${ }^{22}$ (2001) reported that most superelastic archwires commercially available present Af ranging from $22^{\circ} \mathrm{C}$ to $28^{\circ} \mathrm{C}$, while thermally activated archwires present Af with temperatures ranging from $35^{\circ} \mathrm{C}$ to $40^{\circ} \mathrm{C}$.

The archwires Nitinol Termoativado, Thermo Plus and Superthermal Nickel Titanium Arches analyzed in this study presented TTR ranging from $-42.36^{\circ} \mathrm{C}$ (Mf) to $24.75^{\circ} \mathrm{C}$ (Af), from $-64.14^{\circ} \mathrm{C}$ (Mf) to $20.39^{\circ} \mathrm{C}$ (Af) and from $-68.68^{\circ} \mathrm{C}$ (Mf) to $24.18^{\circ} \mathrm{C}$ (Af), respectively (Table 1 ). For these archwires, only the austenitic phase is present during orthodontic treatment. The low Af of these archwires indicate that they are in the austenitic phase both at room and oral temperature. Thus, these NiTi archwires do not present the properties of shape memory 
and pseudoelasticity that are desirable in clinical applications. Conversely, Figueiredo, et al. ${ }^{11}$ (2012) compared the mechanical behavior of the same archwires, except for the Heat Activated $\mathrm{NiTi}$, and revealed that these archwires present pseudoelasticity. Evans and Durning ${ }^{10}$ (1996) found Af of $24^{\circ} \mathrm{C}$ for the archwire Thermomemoria (Leone, Oxnard, CA, USA), suggesting similar clinical performance as the aforementioned archwires.

The archwires NeoSentalloy F200 and Heat Activated NiTi presented TTR in this study ranging from $-51.60^{\circ} \mathrm{C}(\mathrm{Mf})$ to $29.37^{\circ} \mathrm{C}$ (Af) and from $-64.13^{\circ} \mathrm{C}$ (Mf) to $33.90^{\circ} \mathrm{C}$ (Af), respectively (Table 1 ). These results agree with the studies of Bishara, et al. ${ }^{5}$ (1995) who analyzed 10 specimens of archwire NeoSentalloy size $0.018^{\prime \prime} \times 0.025^{\prime \prime}$ and found a TTR of $21^{\circ} \mathrm{C}$ to $28.8^{\circ} \mathrm{C}$. Santoro, Nicolay and Cangialosi22 (2001) reported Af of $28^{\circ} \mathrm{C}$ for archwire NeoSentalloy in the absence of deflection and Af of $36^{\circ} \mathrm{C}$ with load application. Brauchli, et al. ${ }^{8}$ (2011) found Af of $29.2^{\circ} \mathrm{C}$ for archwire NeoSentalloy size $0.016^{\prime \prime} \times 0.022^{\prime \prime}$. Conversely, Evans and Durning ${ }^{10}$ (1996) observed Af of $68^{\circ} \mathrm{C}$ and $\mathrm{Mf}$ of $24^{\circ} \mathrm{C}$ for archwire Heat Activated NiTi size 0.016"x0.022", which disagrees with this study. The present results suggest that these two archwires present the best clinical performance considering the shape memory effect and pseudoelasticity property, since the Af of these archwires is closer to the oral temperature.

The archwires Copper $\mathrm{Ni}-\mathrm{Ti} 35^{\circ} \mathrm{C}$ and Flexy Thermal $35^{\circ} \mathrm{C}$ in this study presented $\mathrm{TTR}$ ranging from $-24.56^{\circ} \mathrm{C}(\mathrm{Mf})$ to $42.64^{\circ} \mathrm{C}$ (Af) and from $16.68^{\circ} \mathrm{C}$ (Mf) to $45.42^{\circ} \mathrm{C}$ (Af), respectively (Table $1)$. These archwires may be considered truly superelastic at the oral temperature, at which they exhibit a mixture of martensite/austenite and do not present shape memory during clinical applications. Brantley, Iijima and Grentzer $^{7}$ (2003), using the modulated DSC, found Af of $35^{\circ} \mathrm{C}$ for archwire Copper $\mathrm{Ni}-\mathrm{Ti} 35^{\circ} \mathrm{C}$ size $0.016^{\prime \prime} \times 0.022^{\prime \prime}$. Biermann, Berzins and Bradley ${ }^{4}$ (2007) evaluated the Af of archwires Copper NiTi $35^{\circ} \mathrm{C}$ by the DSC and concluded that the Af of this archwire presents variability of $\pm 2{ }^{\circ} \mathrm{C}$ compared to values informed by the manufacturer. Conversely, Laino, et al. ${ }^{16}$ (2012), in a sample of five archwires Copper $\mathrm{Ni}-\mathrm{Ti}$ $35^{\circ} \mathrm{C}$ size $0.016^{\prime \prime} \times 0.022^{\prime \prime}$, also used the DSC method for thermal scanning of these archwires and found Af of $34.4^{\circ} \mathrm{C}(\mathrm{SD} \pm 2.1)$. Brauchli, et al. ${ }^{8}$ (2011) analyzed a sample of 10 specimens of archwires Copper NiTi $35^{\circ} \mathrm{C}$ size $0.016^{\prime \prime} \times 0.022^{\prime \prime}$ and found Af of $27.4^{\circ} \mathrm{C}(S D \pm 0.51)$. In this study, the Af of archwires Copper $\mathrm{Ni}-\mathrm{Ti} 35^{\circ} \mathrm{C}$ and Flexy Thermal $35^{\circ} \mathrm{C}$ was substantially higher than informed by the manufacturers, namely $35^{\circ} \mathrm{C}$. These results reveal that the transition of martensite in austenite only occurs in these archwires when the oral temperature is above the normal, suggesting that the elasticity of these archwires may not reach the best performance in clinical applications.

Therefore, it may be noticed that there is wide variability of Af in NiTi archwires according to the manufacturer or even between batches of the same manufacturer. Thompson ${ }^{23}$ (2000) reported some factors that may contribute to differences in the TTR of NiTi archwires: differences between manufacturers, differences between batches of the same manufacturer, thermal treatment applied on the alloy during the metallurgical process, extent of cold working and ratios of nickel and titanium in the alloy.

The pseudoelasticity property is a localized phenomenon related to stress application on the $\mathrm{NiTi}$ alloy. However, the formation of martensite in the NiTi alloy requires Af of the alloy slightly lower than the oral temperature ${ }^{4-6,21,22}$. Conversely, if the Af of the archwire is considerably lower than the oral temperature, the crystalline structure will always have a tendency to remain in the austenitic phase, and application of a very high stress would be necessary to neutralize the effect of the temperature and maintain the presence of martensite induced by tension ${ }^{22}$. Thus, the austenitic alloy would present a superelastic behavior only in cases with very severe crowding 22 .

The present results should be carefully analyzed, since the TTR of all archwires were calculated in the absence of deflection ("as-received" condition), which does not perfectly represent the clinical conditions of the oral cavity. It is known that stress application in thermally activated NiTi alloys increases the Af of these archwires ${ }^{22}$. Coluzzi, et al. ${ }^{9}$ (1996) evaluated the effect of stress application in the Af of NeoSentalloy F200 and Thermomemoria (Leone, Oxnard, CA, USA). The authors performed a thermal scanning on these alloys with and without deflection. In the absence of deflection, NeoSentalloy exhibited an Af of $28^{\circ} \mathrm{C}$. Af increased proportionally with loading to a maximum of $34^{\circ} \mathrm{C}$. Thermomemoria wire had an Af in unloaded conditions set at $20^{\circ} \mathrm{C}$ and increased to a maximum of $35^{\circ} \mathrm{C}$ with stress application.

For nearly all archwires analyzed, except for Copper $\mathrm{NiTi} 35^{\circ} \mathrm{C}$ and Flexy Thermal $35^{\circ} \mathrm{C}$, there was presence of the R phase (rhombohedral) during cooling. This result corroborates the findings of Iijima, et al. ${ }^{13}$ (2002) and Fisher-Brandies, et al. ${ }^{12}$ (2003), who also did not observe rhombohedral phase ( $R$ ) in phase transition for archwire Copper $\mathrm{NiTi} 35^{\circ} \mathrm{C}$. However, Brantley, Iijima and Grentzer ${ }^{7}$ (2003) observed the rhombohedral phase both on warming and cooling for the archwire Copper NiTi $35^{\circ} \mathrm{C}$, which is similar to the reports of Bradley, Brantley and Culbertson ${ }^{6}$ (1996) and Todoroki and Tamura24 (1987). 


\section{Clinical implications}

One of the main properties of thermally activated NiTi archwires is the release of light and continuous forces, even when submitted to great deflections. This force characteristic is highly desirable in the initial stages of orthodontic treatment, favoring tooth movement with low risk of root resorption and damage to the supporting tissues and less pain by the patient.

In some clinical situations, thermally activated rectangular $\mathrm{NiTi}$ archwires may be inserted in brackets in the initial stages of treatment, delivering light and continuous forces and allowing threedimensional control of tooth movement.

Considering the archwires analyzed in this study, only NeoSentalloy F200 and Heat Activated NiTi presented Af corresponding to the temperature variations in the oral cavity. At room temperature, these archwires are flexible and easily deformable, which allows for easy insertion in slots of brackets bonded on misaligned teeth. With the increased temperature in the oral cavity, there will be phase transformation to austenite, leading these archwires to acquire greater rigidity and releasing light and continuous forces, allowing tooth alignment.

The archwires Nitinol Termoativado, Thermo Plus and Superthermal Nickel-Titanium Arches presented Af close to room temperature and lower than the oral temperature, being completely in austenitic phase (greater rigidity) for clinical applications. When these archwires are used, the orthodontist may hardly insert rectangular archwires in the bracket slot of misaligned teeth in initial treatment stages. These archwires are marketed as thermally activated, yet they do not present the shape memory and pseudoelasticity properties required for clinical applications in orthodontics, behaving as first-generation or cold-worked nickel-titanium archwires. These archwires present a superelastic behavior only in cases with very severe crowding.

The archwires Copper $\mathrm{Ni}-\mathrm{Ti} 35^{\circ} \mathrm{C}$ and Flexy Thermal $35^{\circ} \mathrm{C}$ presented higher Af than the oral temperature, with great quantity of martensite both at room and oral temperatures, being extremely flexible and malleable and delivering very low forces on the dentoalveolar structures. Therefore, these archwires may be used in patients with periodontal involvement and low pain threshold. In these cases, the orthodontist should guide the patient to ingest warm drinks to temporarily increase the force delivered by these archwires and stimulate tooth movement. Conversely, cold drinks reduce the force delivered by these archwires.

\section{CONCLUSIONS}

The thermally activated NiTi archwires present great variability in the TTR with Af ranging from $20.39^{\circ} \mathrm{C}$ to $45.42^{\circ} \mathrm{C}$. Thus, the elastic parameters of each NiTi archwire should be provided by the manufacturers, to allow achievement of the best clinical performance possible.

\section{REFERENCES}

1- Airoldi G, Riva G, Vanelli M, Filippi V, Garattini G. Oral environment temperature changes induced by cold/hot liquid intake. Am J Orthod Dentofacial Orthop. 1997;112:58-63.

2- American Society for Testing and Materials. D3418-08: Standard test method for transition temperatures and enthalpies of fusion and crystallization of polymers by differential scanning calorimetry. West Conshohocken: ASTM; 2008.

3- Berzins DW, Roberts HW. Phase transformation changes in thermocycled nickel-titanium orthodontic wires. Dent Mater. 2010;26:666-74.

4- Biermann MC, Berzins DW, Bradley TG. Thermal analysis of asreceived and clinically retrieved copper-nickel-titanium orthodontic archwires. Angle Orthod. 2007;77:499-503.

5- Bishara SE, Winterbottom JM, Sulieman AH, Rim K, Jakobsen JR. Comparisons of the thermodynamic properties of three nickeltitanium orthodontic archwires. Angle Orthod. 1995;65:117-22. 6- Bradley TG, Brantley WA, Culbertson BM. Differential scanning calorimetry (DSC) analyses of superelastic and nonsuperelastic nickel-titanium orthodontic wires. Am J Orthod Dentofacial Orthop. 1996;109:589-97.

7- Brantley WA, Iijima M, Grentzer TH. Temperature-modulated DSC provides new insight about nickel-titanium wire transformations. Am J Orthod Dentofacial Orthop. 2003;124:387-94.

8- Brauchli LM, Keller $H$, Senn C, Wichelhaus A. Influence of bending mode on the mechanical properties of nickel-titanium archwires and correlation to differential scanning calorimetry measurements. Am J Orthod Dentofacial Orthop. 2011;139:e44954.

9- Coluzzi B, Biscarini A, Di Masso L, Mazzolai F, Staffolani, Guerra M, et al. Phase transition features of NiTi orthodontic wires subjected to constant bending strains. J All Comp. 1996;233:197205.

10- Evans TJ, Durning P. Aligning archwires, the shape of things to come?--a fourth and fifth phase of force delivery. $\mathrm{Br}$ J Orthod. 1996;23:269-75.

11- Figueiredo MM, Cançado RH, Freitas KM, Valarelli FP. Comparison of deactivation forces between thermally activated nickel-titanium archwires. J Orthod. 2012;39:111-6.

12- Fischer-Brandies H, Es-Souni M, Kock N, Raetzke K, Bock O. Transformation behavior, chemical composition, surface topography and bending properties of five selected 0.016 "x0.022" NiTi archwires. J Orofac Orthop. 2003;64:88-99.

13- Iijima M, Ohno H, Kawashima I, Endo K, Mizoguchi I. Mechanical behavior at different temperatures and stresses for superelastic nickel-titanium orthodontic wires having different transformation temperatures. Dent Mater. 2002;18:88-93.

14- Iijima M, Ohta M, Brantley WA, Naganishi A, Murakami T, Muguruma $\mathrm{T}$, et al. Transformation behavior of nickel-titanium orthodontic wires under tensile load. Dent Mater J. 2011;30:398403.

15- International Organization for Standardization. ISO 15841: Dentistry: Wires for use in orthodontics. Geneva: ISO; 2006.

16- Laino G, De Santis R, Gloria A, Russo T, Quintanilla DS, Laino $A$, et al. Calorimetric and thermomechanical properties of titaniumbased orthodontic wires: DSC-DMA relationship to predict the elastic modulus. J Biomater Appl. 2012;26:829-44.

17- Longman CM, Pearson GJ. Variations in tooth surface temperature in the oral cavity during fluid intake. Biomaterials. 1987;8:411-4.

18- Mallory DC, English JD, Powers JM, Brantley WA, Bussa $\mathrm{HI}$. Force-deflection comparison of superelastic nickel-titanium archwires. Am J Orthod Dentofacial Orthop. 2004;126:110-2. 
19- Miura F, Mogi M, Ohura $Y$, Hamanaka H. The super-elastic property of the Japanese NiTi alloy wire for use in orthodontics. Am J Orthod Dentofacial Orthop. 1986;90:1-10.

20- Ren CC, Bai YX, Wang HM, Zheng YF, Li S. Phase transformation analysis of varied nickel-titanium orthodontic wires. Chin Med J (Engl). 2008;121:2060-4.

21- Sakima MT, Dalstra M, Melsen B. How does temperature influence the properties of rectangular nickel-titanium wires? Eur J Orthod. 2006;28:282-91.

22- Santoro M, Nicolay OF, Cangialosi TJ. Pseudoelasticity and thermoelasticity of nickel-titanium alloys: a clinically oriented review. Part I: Temperature transitional ranges. Am J Orthod Dentofacial Orthop. 2001;119:587-93.
23- Thompson SA. An overview of nickel-titanium alloys used in dentistry. Int Endod J. 2000;33:297-310.

24- Todoroki T, Tamura H. Effect of heat treatment after cold working on the phase transformation in TiNi alloys. Trans Jpn Instit Metals. 1987;28:83-94.

25- Volchansky A, Cleaton-Jones P. Variations in oral temperature. J Oral Rehabil. 1994;21:605-11.

26- Yoneyama T, Doi H, Hamanaka H, Yamamoto M, Kuroda T. Bending properties and transformation temperatures of heat treated $\mathrm{Ni}$-Ti alloy wire for orthodontic appliances. J Biomed Mater Res. 1993;27:399-402. 